\title{
ENTREPRENEURSHIP IN CULTURAL AND CREATIVE INDUSTRIES AS A FACTOR PROMOTING REGIONAL DEVELOPMENT
}

\author{
Kaspars Steinbergs ${ }^{1}$, Dr.oec.; Renate Cane ${ }^{2}$, Dr.sc.soc.
}

${ }^{1}$ EKA University of Applied Sciences; ${ }^{2}$ Vidzeme University of Applied Sciences

\begin{abstract}
The term creative industries began to be used in the second half of the nineties of last century, and since then it has started to appear in scientific research as well in the policy planning documents and processes in Latvia.

For example, The Sustainable Development Strategy of Latvia until 2030 emphasizes both the importance of creative industries and the connection with the formation of a creative urban environment. The National Development Plan of Latvia for 2021-2027 highlights the importance of development of small businesses, including in creative industries and tourism in economically weaker regions.

However, the development of creative industries entrepreneurship in the regions of Latvia is a little-studied topic so far. Previous studies on creative industries focus on their development in Riga, on their role in economic development and on general conceptual ideas. Aim of this study is to analyse activities set in the municipal planning documents to promote the development of creative industries and to assess the impact of creative industries entrepreneurship on regional development. The research is based on the analysis of the regional policy planning documents and on interviews with representatives of creative industries and with regional development planners.

Research results showed that, while national policy planning documents stress that creative industries have an important role in the regional development, only a small number of local development plans highlight this role. Moreover, these documents are not always properly and effectively implemented. On the other hand, case studies showed that appropriate initiatives foster entrepreneurship in creative industries and they can play a key role in regional development.
\end{abstract}

Key words: creative industries, planning documents, regional development.

JEL code: R58, R11, O25

\section{Introduction}

The term creative industries and its concept has evolved since the 1990s - first in the UK and then globally (Kong L., 2020; Banks M. and O' Connor J., 2009; Flew, T. and Cunningham S., 2010) including Latvia (Moore I., 2014; Daubaraite U. and Startiene G, 2017). Initially, the concept developed in policy planning, then in research and later in educational programs (Flew T., 2011; Flew T., 2019 ; Galloway S. and Dunlop S., 2007). For example, in policy planning, the creative industries were mentioned in Latvia already in 2005, when the new cultural policy guidelines were developed. (Study "Creative industry sector development", 2012). As the term cultural industries was used same time, joint term cultural and creative industries (or CCI) has been used internationally and also in Latvia (for the sake of convenience, the term creative industries will be used in this article).

At present, in Latvia, creative industries are understood as "those cultural industries and related industries that primarily use business models in their activities, creating a significant economic contribution to the national economy in parallel with a cultural capital" (Cultural policy guideline 2021-2027). Such an approach means a greater focus on the economic potential of the cultural sector and from the cultural economy viewpoint. Thus, the approach of "competition model" by Potts and Cunningham is used as the concept of creative industries in Latvia. Within this approach companies of creative industries use same business models as in other industries. With such an approach, the development of creative industries can be fostered through similar support instruments as in other industries (Potts J. and Cunningham S., 2008).

At the national level, the development of creative industries is, first of all, related to the provisions of the Latvian Sustainable Development Strategy for 2030. The focus of the strategy is on creativity as the most important factor in the development of the state and society and the competitiveness of companies. 
The development of such creative industries as design, advertising and tourism is associated with the competitiveness of national identity, but the products of creative industries such as festivals, film production, computer games, music recordings are assessed as with a high export potential. In addition, this document emphasizes factors that are important for the development of creative industries: cultural education, creative urban environment (especially creation of contemporary cultural centres and creative clusters), creative tourism. The strategy recognizes that entrepreneurship in the creative industries is essential for development of both cities and regions. One indicator is set to assess the development of creative industries - the share of creative industries export in the total export of the country, which should be $3 \%$ in year 2030 (base value $-0.73 \%$ ).

One of the action directions of the National Development Plan of Latvia for 2014-2021 - a medium-term national planning document - is high-productivity and export-oriented production and internationally competitive services, incl. "commercial creative industries". The indicators to be achieved in 2020 are also determined: the share of export of creative industries - $1.6 \%$, and the share of companies working in the cultural and creative industries - $7.5 \%$. To achieve this, the following support activities are identified: a support instrument for the development of creative industries; promoting the export capacity of the companies, and support for "creative industries design activities". It is planned to apply all activities to the entire territory of Latvia.

In order to evaluate the achievements of the planning documents, progress of set goals and indicators is regularly evaluated. In 2015, the indicators set in the Sustainable Development Strategy were monitored, concluding, among other things, that the share of export of creative industries cannot be calculated because there is no clear definition of "so-called creative industries". The share of creative industries companies is not calculated, because "existing classifiers do not allow to distinguish companies of this profile". The report on the achieved results of the strategy and development plan in 2015 states that the creative industries are not developing fast enough due to the lack of state support for both the creative industries and innovation. It has also been pointed out that the creative industries are too focused on the local market. Overall, this leads to the conclusion that "(...) all parties involved lack an understanding of the potential of the creative industries".

In fact, it is acknowledged that there are no statistics and other quantitative indicators that would allow to assess results of development priorities and actions for creative industries that are set in the national planning documents, like progress towards the set goals and indicators. In addition, the low level of implementation of the planned activities is also pointed out. At the regional level, data are not available at all and no evaluation is carried out.

However, priorities set out in the national planning documents should be assessed at the regional level. The emphasis of local planning documents and their support measures should be identified. At the local level development of the creative industries are influenced by cultural and business infrastructure, local government awareness and priorities, the development of related industries and the activity of the local community. For creative industries development planning and support activities at the local level are as important as in national level (Fleischmann K. et al., 2017; Cerneviciute J. et al., 2019; Sternberg R., 2012; Rivas M., 2011).

Research hypotheses is: entrepreneurship of creative industries in the regions promotes the attraction of intellectual capital, the development of social infrastructure and the diversification of economic activities. The aim of this article is to analyse activities set in the municipal planning documents to promote the development of creative industries and to assess the impact of creative industries entrepreneurship on regional development. The research tasks are: 1) to assess the sustainable development strategies and 
development programs of the planning regions and municipalities for the period from 2014 to 2020; 2) to interview representatives of creative industry companies, municipalities, as well as experts in these subjects; 3 ) to assess the impact of planned activities on the development of creative industries and the role of their entrepreneurship in regional development.

Qualitative research methods were chosen because of the absence of quantitative indicators at either national or regional level.

Such an analysis is essential as new support instruments are currently being planned at national level, as well as new development strategies and programs are being developed in the new municipalities.

At the level of academic discourse, creative industries in Latvia have not been studied at the regional and municipal level so far. Existing research focuses on general business management issues in the creative industries (Kuttim M. et al., 2011; Dunska M. and Marcinkevica A., 2018; Berzins G., 2011) development of entrepreneurship in creative industries (Muradli, R. and Volkova, T., 2015; Dunska M. and Marcinkevica A., 2017) and case studies (Rozentale I., 2014).

\section{Research results and discussion}

\section{Analysis of planning region documents}

The development priorities of Latvia's planning regions are included in their sustainable development strategies for 2030 and in their development programs for 2020. Clearly, the development of all planning regions is linked to the creative and cultural industries, but the scope and emphasis are different. Great importance of the creative industries can be identified in the documents of the Riga Planning region, which states that "the preconditions for the development of the Riga Planning region, in the context of the Baltic Sea region, are the green environment, creative industries, information technology development, foreign language skills". The development of creative industries in the Riga Planning region has played an important role in positioning them as globally competitive industries in the region. The planning documents in order to promote their development, plan the formation of clusters, the implementation of regional cultural policy, the establishment of new companies, the development of cultural infrastructure and the organization of festivals of cultural and historical traditions. Design and fashion are mentioned as the most important creative industries in the region.

Creative industries as one of the perspective development sectors of the region are also mentioned in the documents of Vidzeme Planning region. This is due to "the high share of the creative class in the region", especially in craft and printing professions, developed cultural infrastructure, and the rapid growth of turnover and employment of creative industries. In the regional planning documents, the development of creative industries is viewed together with the tourism and cultural heritage.

The documents of Latgale Planning region place more emphasis on creativity, cultural heritage, traditions. They point out the role of cities of Daugavpils and Rezekne in the development of creative industries.

One of the development priorities for the Kurzeme Planning region is "Creative Kurzeme 2020", which also includes the development of cultural education and creative industries in the region, with special focus on the potential for creative industries in Kuldiga and Liepaja.

The development of creative industries in Zemgale Planning region is related to the cultural environment and identity of the region, especially supporting the development of crafts, home production and cultural and creative industries. 


\section{Analysis of planning documents of local municipalities}

The role of creative industries at the local level was analysed by studying the municipal development planning documents. Municipal planning documents from the State Unified Geospatial Information Portal, as well as additional sectoral planning documents available on municipal websites were used for the analysis. This analysis was performed for all 110 of the one-level municipalities (counties) and 8 republican cities (except Riga), and documents adopted in the period from 2014 to 2020 were analysed. Such a period corresponds to the medium-term planning in Latvia, as well as 2020 marked the beginning of the administrative-territorial reform.

In general, local government development is defined in two types of documents: the sustainable development strategy, which is a long-term planning document of local governments, and the development program, which is a medium-term document with short-term action plans and investment programs. Some municipalities have also developed sectoral strategies for example, in culture or education. Data and information on the development of creative industries were studied in all planning documents. In total, the development of creative industries was mentioned in 36 municipal documents, which is approximately $30.5 \%$ of all municipalities (including all republican cities, except Jekabpils). Other documents addressed relevant topics, such as cultural infrastructure development, business support, sectoral policies, but these topics were not related to the creative industries. The distribution of these 36 municipalities by Latvia's Planning regions is shown in Table 1.

Table 1

\section{Number of municipalities whose planning documents mentioned the development of creative industries (amount, \%)}

\begin{tabular}{|c|c|c|c|c|c|}
\hline Planning Region & Kurzeme & Zemgale & Riga & Vidzeme & Latgale \\
\hline Amount & 7 & 6 & 7 & 10 & 6 \\
\hline $\begin{array}{c}\text { In \% on all municipalities } \\
\text { of the planning region }\end{array}$ & $35 \%$ & $27 \%$ & $24 \%$ & $38,5 \%$ & $29 \%$ \\
\hline
\end{tabular}

\section{Source: authors' compilation}

Both in general and as a percentage, in Vidzeme Planning region, the importance of creative industries is emphasized in the planning documents the most, but the least - in Riga and Zemgale regions. This could be related to other sectors traditionally developed in these regions.

Municipalities whose planning documents emphasize the importance of creative industries differ not only in their geographical location, but also in other indicators, such as population density or level of development (Table 2).

Table 2

\section{Municipality distribution by population density, by actual place of residence in 2020 (population per $\mathbf{k m}^{2}$ )}

\begin{tabular}{|c|c|c|c|c|}
\hline Population density & $<10$ & $10-100$ & $100-1000$ & $1000>$ \\
\hline Number of municipalities & 11 & 15 & 6 & 4 \\
\hline
\end{tabular}

Source: authors' compilation based on data by the Central Statistical Bureau of Latvia

These data confirm that the development of creative industries can be determined to be significant both in municipalities with a high population density, such as republican cities and in sparsely populated counties, such as Dundaga and Naukseni.

In addition to population density, other indicators characterizing the development of the municipality are also important, which have been included in the territorial development index in Latvia since 2013. The 
territorial development index characterizes the level of development of each administrative territory. The rankings of the mentioned 36 municipalities in the development index in 2019 are shown in Table 3.

Table 3

\section{Distribution of municipalities by territorial development index in $2019^{3}$}

\begin{tabular}{|c|c|c|c|c|}
\hline Rating place & $1 .-10$. & $11 .-50$. & $51 .-100$. & $101 .+$ \\
\hline Number & 12 & 7 & 16 & 1 \\
\hline
\end{tabular}

\section{Source: authors' compilation based on data by the State Regional Development Agency}

The importance of creative industries is emphasized both in the planning documents of highly developed municipalities (republican cities and counties nearby Riga) and less developed local governments, for example, in Zilupe and Riebini municipalities in Latgale. This generally confirms that very different municipalities see the importance of creative industries. However, in order to analyse whether the development of creative industries has any impact on the overall development of the municipality, it is necessary to take into account the changes in this index in the long run. In general, comparing the ranking of selected municipalities in 2014 and 2019, it can be seen that the positions of 20 local governments have increased (ten municipalities have increased by five or more places), six municipalities have not changed their positions, ten municipalities have decreased their positions (six municipalities have decreased for five or more places). The fastest growth in this period has been in counties of Dundaga, Jelgava, Rundale and Valka, but the fastest decline - in counties of Preili and Talsi. Analysing the indicators that make up the index, it can be concluded that the most significant increase or decrease in the rating has been influenced by changes in the number of companies and the balance of natural movement per 1000 inhabitants. It should be noted that purposeful actions of municipalities in promoting the creative industries also promotes the formation of micro and small enterprises.

Analysis of the planning documents focused on two issues: what is mentioned in the documents about creative industries, and what is the role of creative industries in the development of the municipality. During the thematic analysis of the planning documents, it was identified which sectors are being discussed in the context of the creative and cultural industries. The craft sector was mentioned most often - in planning documents of 12 municipalities. It was mentioned as one of the creative industries and as well as a related sector. Other industries were mentioned as well - the design sector and the visual arts were pointed out in the development plans of more than three municipalities. Tourism, and in particular cultural tourism, was mentioned as a sector linked to the development of creative industries, promoting synergies. The preservation and development of cultural heritage was also mentioned very often in connection with the creative industries.

In planning documents specific tasks, development activities for the development of creative industries were mentioned. The need for various support instruments, programs, grants, establishment of business support centres were mentioned the most. An important factor in the development of creative industries is the creation of appropriate infrastructure - such as a rebuilding or creation of cultural objects, the creation of infrastructure necessary for the work of creative professionals. Equally important place in planning documents is given to the promotion of new products and companies in the creative industries. Several planning documents emphasize the importance of educational institutions both in higher education, for example, in Liepaja and Rezekne, and in the secondary and vocational education. Equally often, the focus is on the creation or promotion of creative quarters, thus creating an environment for the development of

3 Note: separate ratings are used for county municipalities and republican city municipalities, thus all republican cities will be ranked from place $1-9$. 
new companies, cooperation and the development of a creative environment. An important role is also given to the creation and promotion of creative incubators, co-creation spaces.

In general, all analysed municipal planning documents, can be divided into three groups according to the importance of creative industries in them. The first group consists of planning documents in which the creative industries are mentioned without specific actions, planned activities or other details. That is situation in 17 municipal planning documents. This shows that in large part of planning documents the development of creative industries is just mentioned, as it is emphasized in the state level or planning region documents, but they do not indicate specific actions to be performed. Similar number (15) of municipal planning documents propose specific tasks and activities for the development of creative industries, and list priority creative industries. In some municipalities, such activities have been developed in great detail - separate cultural policy planning documents have been approved, for example, in the city of Jurmala and counties of Valka and Gulbene. Finally, in the planning documents of four municipalities, creative industries are identified as an important factor promoting the development of the municipality, namely, in counties of Cesis, Kuldiga, Riebini and city of Rezekne. In all four municipalities, the creative industries are part of their development visions. For example, the county of Kuldiga positions itself as follows: "Kuldiga - a unique, internationally recognized place of cultural and natural heritage, a city of tourism and creative industries and a centre of regional significance". The development documents of Cesis municipality declare that "Cesis municipality has a strong and competitive identity. It is an economically active centre of creative, digital and cultural industries of national significance". The following development vision is set for the city of Rezekne: "Rezekne is an important centre of economy, culture, creative industries, education, research and sports in Eastern Latvia". The development documents of the small county of Riebini points out that "in the future it is not "one of" but "the well-known county of Riebini, which stands out with its non-traditional thinking and actions (homeland of R. Muks), traditions of craft masters (Ceramics school of Silajani), and creativity; the use of creative industries in the growth of the region (the legacy of J. Pigoznis, J. Ivanovs, J. Streics).". The planning documents of these municipalities mention creative industries as one of the most important sectors of their economy; specific and various instruments are provided for their development; but most importantly - creative industries occupy a strategically important place in the development of these municipalities.

However, the analysis of changes of the municipal territorial development index from 2014 to 2019 does not allow to draw unambiguous conclusions to what degree planned activities have been successful, including activities for the development of creative industries and their impact on the development of the municipality in general. For example, the territorial development index for county of Cesis has slightly increased during this period, while for county of Kuldiga it has significantly decreased. Consequently, it is necessary to assess not only what is set in the planning documents, but also what has actually been achieved.

\section{Interviews with experts, representatives of creative industries companies and municipalities}

In order to investigate the feelings of the entrepreneurs of cultural and creative industries in the regions, what their contribution to the development of the various regions of Latvia is, and how it correlates with what has been stated in the planning documents, the qualitative research method interview was used. Ten structured and semi-structured interviews were conducted with representatives of four audiences. Six interviews were conducted by telephone, four interviewees answered questions in writing. 
Qualitative research interview respondents

\begin{tabular}{|c|c|c|}
\hline Nr. & Name & Status \\
\hline 1. & Atis Eglins-Eglitis & $\begin{array}{l}\text { Head of Cesis Municipality Administration, previously Member of the Board at } \\
\text { Liepaja Creative Industry Cluster }\end{array}$ \\
\hline 2. & Dita Trapenciere & $\begin{array}{l}\text { Chairperson of the board of Cesis Creative Industries Center - co-creation } \\
\text { house "Skola6" }\end{array}$ \\
\hline 3. & Inga Berzina & $\begin{array}{l}\text { Chairperson of Kuldiga District Council, Chairperson of the Development } \\
\text { Council of Kurzeme Planning District, Member of the EU Committee of } \\
\text { Regions Latvian Delegation }\end{array}$ \\
\hline 4. & Skaidrite Baltace & $\begin{array}{l}\text { Head of Rezekne Business Incubator (Investment and Development Agency of } \\
\text { Latvia) }\end{array}$ \\
\hline 5. & Kristine Klane & $\begin{array}{l}\text { Owner and manager of the digital advertising company SIA KADD, Aizpute, } \\
\text { Kurzeme region }\end{array}$ \\
\hline 6. & Sandra Balode & $\begin{array}{l}\text { Founder of the screen printing workshop Aizpute and the brand Aizputes krekli, } \\
\text { Aizpute, Kurzeme region }\end{array}$ \\
\hline 7. & Velga Krukovska & $\begin{array}{l}\text { Fashion artist Velga Krukovska, developer of the VelgaCode brand, } \\
\text { performer of economic activity, Rezekne, Latgale region }\end{array}$ \\
\hline 8. & Zelma Pigozna & $\begin{array}{l}\text { Owner and manager of the creative industry company SIA Zel\&K (brand Zelma } \\
\text { Kraft), Lejas Anchupani, Veremu parish, Rezekne county, Latgale } \\
\text { region }\end{array}$ \\
\hline 9. & Lilita Sparane & $\begin{array}{l}\text { Head of the Creative Industries Division, Ministry of Culture, Republic of Latvia } \\
\text { (2017-2018); Advisor, Founder \& Facilitator of Demola Latvia (part of Demola } \\
\text { Network) }\end{array}$ \\
\hline 10. & Aris Adlers & $\begin{array}{l}\text { Representative of the Council of Cooperation Memorandum between NGOs and } \\
\text { the Cabinet of Ministers, Member of the council of the association } \\
\text { Latvian Rural Forum, President of the Alliance for Sustainable Cross-Sectoral } \\
\text { Development (APIA) }\end{array}$ \\
\hline
\end{tabular}

The selection of respondents was performed in such a way as to comprehensively cover the range of issues to be considered, as well as the situation in different regions of Latvia:

- The heads of two (out of a total of four) municipalities whose planning documents identify creative industries as an important factor in promoting the development of the municipality, namely - from Cesis and Kuldiga municipalities, were asked to answer questions about the role of municipalities in emerging industries. and the region benefits from these companies;

- The head of the Rezekne business incubator of the Latvian Investment and Development Agency was interviewed to describe the situation in Latgale and the possibilities of state support for cultural and creative industries companies;

- Four creative entrepreneurs from rural areas representing the fashion, souvenir and advertising industries were interviewed. They were asked what support they have received so far from the various institutions, as well as what other support they would like to receive;

- Two experts from regional development and creative industries were interviewed, who outlined the overall picture, the conditions affecting the activities of creative industries companies in the regions and the future perspectives of the field.

- The interview data were categorized according to these four main topics and interpreted accordingly. The conclusions of the interviews were correlated with the main findings from the document analysis performed earlier in this study. 
Evaluating the opportunities of local governments in the development of creative industries entrepreneurship, Head of Cesis Municipality Administration admits that there must be not only a document-based approach, but also the right attitude and concrete action on the part of the local government. Cesis municipality has several successful examples that confirm that the potential of creative industries has been assessed and developed. Several long-term initiatives of non-governmental organizations have been supported - the Rucka Art Foundation successfully develops an international art residency center in Rucka Manor, the World Latvian Art Center in Cesis has opened a permanent exhibition hall, the Skola6 creative house encourages the development of creative industries and is developing a coworking platform, the association Art Cesis annually organizes a painting plain air, ensuring the presence of professional visual art in the city. There are several reasons why Cesis municipality has chosen such a direction. First of all, Cesis and a large part of the territory of Cesis region are located in the territory of the Gauja National Park, which imposes significant restrictions on the use of the territory, and thus it is not possible to talk about massive industrial development. Another important factor is that in Cesis, as a city and also in the county, there are many historical objects owned by the municipality, the maintenance and use of which is regulated by regulatory enactments for the protection of cultural monuments, and their management would require large resources. Thus, Cesis municipality has chosen the cultural sector and creative economy as an alternative and logical direction of strategic development, and the Cesis Region Cultural Development Strategy 2030 has been created for its development.

One of the most important factors for the implementation of the strategy is to have the appropriate human resources: "We understand that the population is the currency and source of income of any municipality, therefore the municipalities have an interest in attracting the population. We have decided that the development of Cesis requires comprehensively educated intellectuals who have a good income." There is one positive factor in attracting such people to Cesis - it is the proximity of Riga (only $90 \mathrm{~km}$ to the capital). In recent years, there has been a stable tendency for young people to move to Cesis from Riga, and many of them are representatives of the creative industries. Cesis has managed to stop internal migration - in 2018, 566 residents came to live in Cesis, but 550 left.

The business areas of creative industries in Cesis are various, and most often they are also interconnected and complement each other. For example, the tourism business is closely connected with the development of historical heritage, designers are involved in the production of furniture, and food tourism has developed in the catering business as a direction. And most importantly, as Head of Cesis Municipality Administration admits, this common synergy creates a transfer effect - such business activities have a significant impact on the urban environment, and the so-called 'vibration' occurs - city and county infrastructure changes, active business environment and nightlife emerge (relatively a rare phenomenon outside the capital), all of which inspires the local community, as well as magnetizing and attracting talent and young creative residents. Currently, Cesis is one of the few places in the country with the largest share of highly educated people.

One of the success stories of Cesis municipality, from which other municipalities can also be inspired in the development of the creative environment, is Cesis Creative Industries Center-co-creation house School 6. When Cesis Vocational Secondary School moved to new premises in the summer of 2015, the historic building in the centre of the Old Town remained empty. It was expensive to continue to manage it without a specific goal, and the municipality of Cesis decided to look for a solution on how to adapt these premises to new functions, while removing the financial burden from the municipality. Exploring experiences elsewhere in Europe led to the initiative to set up a centre for the creative industries, which became a municipal foundation. In this project, the municipality initially invested tens of thousands of euros 
in the form of a grant for the maintenance of a $600 \mathrm{~m} 2$ historic building. Starting from the third year of operation, this centre has become economically independent, but the municipality still supports the centre's programs or creative activities in the form of grants and in other ways. Head of the centre, admits that such a project would not be possible with private funds alone, and the current model has achieved very good results: the centre has 45 residents, 36 lease and cooperation agreements (14 product workshops and 22 office tenants), the represented business lines are designers, graphic designers, clothing sewing, video and photo services, etc. In general, the majority of residents are entrepreneurs in the creative industries.

A similar view as in Cesis is also in Kuldiga municipality. Chairperson of Kuldiga District Council also emphasizes the great importance of creative industries in the development of the region and increase of intellectual potential, but the region has gone a little different, supporting cultural and creative industries, and making significant investments in restoration of Kuldiga historical buildings objects. For example, in 2013, the Artists' Residence of Kuldiga Municipality was established, the aim of which is to develop new talents and energetically strong ideas. Every year, the residence receives artists from both Latvia and abroad, and it is planned to transform this historic Kuldiga building. Since 2019, an art and creative quarter has also been established in Kuldiga, where it is planned to implement international artist programs, organize master classes, creative workshops, seminars, exhibitions and restoration demonstrations. In January 2021, a new innovative project was launched for a relatively small city such as Kuldiga, which combines culture, creative environment and education. The agreement on the establishment of a new international master's program in service design was signed by the Latvian Academy of Arts, Kuldiga Municipality, Kuldiga Artists' Residence and the University of Lapland in Finland, Riga School of Economics, as well as the Estonian Academy of Arts. The international master's level study program "Service Design Strategies and Innovations" in Kuldiga will start already in the autumn of 2021, and it will be a very important, fundamentally new step in the development of the creative environment of the city and region.

Significant contribution to the development of cultural and creative industry business in the regions is provided by the regional business incubators of the Latvian Investment and Development Agency, whose functions are to provide support for business start-up and development for individuals and start-ups. There are 12 regional business incubators throughout Latvia, as well as a Creative Industries Incubator in Riga, which specializes in providing support to creative industries companies. The operation of incubators covers the entire territory of Latvia. There are three business incubators in Latgale - Madona, Daugavpils and Rezekne incubators. Asking to describe cultural and creative entrepreneurship in Latgale, the head of Rezekne Business Incubator, points to two main directions - one of them is the development of large objects (eg Rotko Center or Fortress in Daugavpils, Latgale Embassy GORS, etc.). The second direction is small and even very small companies in the creative industry, which often employ only one entrepreneur. Large objects are created at the expense of the state budget, EU funds and local governments. In turn, small entrepreneurs can receive support both in business incubators (start-up period) and by participating in various project competitions to receive municipal grants. Currently, 60 incubation agreements have been concluded in the Rezekne Business Incubator, and about a third of them are companies operating directly in the creative industries, mainly in the field of design - probably due to the fact that Rezekne Academy of Technology has opportunities to study design in various fields, and former students often start their own businesses.

However, the most important thing that the head of Rezekne business incubator emphasizes is that not only in Rezekne, but also in Latvia as a whole, the so-called 'thistle' or 'snowball' effect works consistently - the strongest objects gather others, including smaller companies, and such operating area in Latgale is 
even 30-50 kilometres. For example, the renovation of the Luznava manor required restoration work, new furniture and other furnishings, gardening services etc., and these services were mostly provided by local entrepreneurs. Even now, when receiving guests at the manor, you can receive meals or listen to the guide's narration. In this way, by supporting different business lines, a multidisciplinary approach is maintained in the region and the dominance of one sector, such as industrial production, is not promoted.

Within the framework of the research, it was also important to understand the opinion of the business representatives of the creative industries on whether sufficient support is received from various institutions, as well as what other support they would like to receive. All four interviewed entrepreneurs (two from Kurzeme, two from Latgale) gave very similar answers and positively assessed the cooperation with local governments, both receiving informative support, including advertising in local media, and receiving financial support (grant) for starting a business within the project competition and development. Two respondents had gone through the incubation process in business incubators, which they very much welcomed. All entrepreneurs also agreed on the issue that the state does not pay enough attention to these areas - "Culture, however, more, but the representatives of the creative industry are stalking themselves as they know (or don't know). Probably because there is no impressive economic contribution from them. There is also a public perception that intellectual work is not worth paying for, as consumers are very spoiled for choice in the market. And right now it's very saturated." However, the most important thing is that all four entrepreneurs, asked to assess their role in local and regional development, were very patriotic: The economic contribution is also important, I pay taxes and I can also support the family budget. And I would like to think that my work also has an intellectual contribution"; "You could definitely contribute to the development of the city and county, and would like to cooperate with the municipality as a company participating in some projects. Ideally, the municipality should first identify and involve local businesses in the development of various projects or, for example, in promoting the city, but only then, if it does not achieve the desired result, look for businesses outside its county."

The main benefits of cultural and creative industries in the business regions were formulated by the two interviewed experts. Like Head of Cesis Municipality Administration, they acknowledged that one of the most important aspects is that the representatives of creative industries in the counties maintain a positive, modern creative atmosphere and create an intellectual environment. Equally important are the diversification of business areas and the creation of new jobs. The contribution to community relations was also emphasized, and in particular to the upbringing of young people, as creative fields often attract and engage young people. There are several municipalities in Latvia that understand that the quality of life is related to the opportunity to live in a place where culture and creativity are of great importance. This awareness gives advantages to local government competition for the population, and smart local governments are able to use it. However, in general, experts acknowledged that the further process of developing the creative industries business will vary from county to county, and much will also depend on the people who will be elected to the new councils after the administrative-territorial reform - their understanding of creative industries entrepreneurship.

\section{Conclusions, proposals, recommendations}

1) The analysis of planning documents showed that at the local municipality level there is not enough understanding of creative industries and promotion of their development, thus most of these documents pay less attention to creative industries than in national or planning region documents.

2) The main benefits of creative industries in business regions are the use or attraction of the intellectual potential of the population, the creation of social infrastructure and an active business 
environment, as well as the development of a multidisciplinary economy - thus confirming our research hypothesis.

3) At the regional level, the interaction of the cultural sector with a business in the creative industries is very important in following areas: crafts, cultural tourism and design. Their development can be facilitated by cultural infrastructure, support for entrepreneurship and a clear vision and priorities of municipal management.

\section{Bibliography}

1. Banks, M., O'Connor, J. (2009). After the Creative Industries. International Journal of Cultural Policy, 15, pp. 365-373.

2. Berzins, G. (2011). Strategic Management in Creative Industries: Specific and Practices in Latvia. Acta Universitatis Latviensis. Economics. Business Administration.

3. Cerneviciute, J., Strazdas, R., Kregzdaite, R., \& Tvaronaviciene, M. (2019). Cultural and Creative Industries for Sustainable Postindustrial Regional Development: The Case of Lithuania. Journal of International Studies. Vol 12(2), pp. 285-298.

4. Daubaraite, U., Startiene, G. (2017). The Role of Creative Industries in Economic Development of Lithuania and Latvia. In Country Experiences in Economic Development, Management and Entrepreneurship (pp. 91-103). Springer, Cham.

5. Dunska, M., Marcinkevica, A. (2017). Situation and Development Opportunities of Creative Industries Companies in Latvia. European Research Studies Journal. 20, pp. 96-114.

6. Dunska, M., Marcinkevica, A. (2018). Lean Effectiveness Method Application in Creative Industries of Latvia. New Challenges of Economic and Business Development-2018: Productivity and Economic Growth, pp. 188199.

7. Galloway, S., Dunlop, S. (2007). A Critique of Definitions of the Cultural and Creative Industries in Public Policy. International Journal of Cultural Policy, 13(1), pp. 17-31.

8. Fleischmann, K., Welters, R., \& Daniel, R. (2017). Creative Industries and Regional Economic Development: Can a Creative Industries Hub Spark New Ways to Grow a Regional Economy?. Australasian Journal of Regional Studies, The, 23(2), pp. 217-242.

9. Flew, T. (2011). The Creative Industries: Culture and Policy. Sage.

10. Flew, T. (2019). From Policy to Curriculum: Drivers of the Growth in Creative Industries Courses in the UK and Australia. Creative Industries Journal, 12(2), pp. 167-184.

11. Flew, T., Cunningham, S. (2010). Creative Industries After the First Decade of Debate. The Information Society, 26(2), pp. 113-123.

12. Kong, L. (2020). From Cultural Industries to Creative Industries and Back? Towards Clarifying Theory and Rethinking Policy. In Handbook on the Geographies of Creativity. Edward Elgar Publishing.

13. Cultural Policy Guideline 2021-2027. Retrieved: https://www.km.gov.lv/lv/pazinojums-08032021. Access: 29.03.2021.

14. Kuttim, M., Arvola, K., Venesaar, U. (2011). Development of Creative Entrepreneurship: Opinion of Managers from Estonia, Latvia, Finland and Sweden. Business: Theory and Practice, 12(4), pp. 369-378.

15. Moore, I. (2014). Cultural and Creative Industries Concept - a Historical Perspective. Procedia-Social and Behavioral Sciences, 110, pp. 738-746.

16. Muradli, R., Volkova, T. (2015). Strategic Innovation Application in Creative Industries in Latvia. Journal of Business Management, (10), pp. 15-26.

17. Study "Creative Industry Sector Development". (2012). SIA "NK Konsultaciju birojs". Retrieved: https://culturelablv.files.wordpress.com/2009/04/petijums-ri-viss-kopa2012.pdf. Access: 29.03.2021.

18. Potts, J., and Cunningham, S. (2008). Four Models of the Creative Industries. International Journal of Cultural Policy, 14(3), pp. 233-247.

19. Rivas, M. (2011). From Creative Industries to the Creative Place: Refreshing the Local Development Agenda in Small and Medium-sized Towns. REDIGE, 2(2).

20. Rozentale, I. (2014). Creative Industries During Economic Recession: the Case of Riga. Regional Studies, Regional Science, 1(1), pp. 329-335.

21. Sternberg, R. (2012). Learning from the Past? Why'Creative Industries' can Hardly be Created by Local/Regional Government Policies. Erde 143 (2012), Nr. 4,143(4), pp. 293-315. 